\title{
Eksistensi Lembaga Kependidikan Islam di Indonesia
}

\section{Mochamad Fuad \\ Universitas Islam Negeri Yogyakarta}

The existence of institutions of Islamic education in Indonesia has been progressing. The progress has been cultural adaptation in response development and social change process without loosing their Islamic essence. Islamic society in Indonesia has agreed that Islamic education are part of Islamic life system, namely the process of intemalization and socialization of Islamic moral values through information or knowledge, attitude, behaviour, and culture to resolve their problems of life, to sustain their life, and to improve quality of life of students and youth generation. Regeneration and development of Islamic education institutions have brought changes to three problems of education, namely fundamental, structural, and operational problems, and will be able to respond problems of education at present.

Keywords: education, industrialization, dan commercialization

D alam seperempat abad terakhir ini masyarakat indonesia mengalami perubahan sosial yang dahsyat. Perubahan tersebut di samping menambah perbendaharaan nilai-nilai sosial, juga telah mengoyak sebagian dari institusi agama, ekonomi, politik dan pendidikan luluh membentuk format baru yang tidak mudah lagi dikenali aslinya.

Getaran perubahan tersebut berawal dari pilihan strategi pembangunan yang dicanangkan oleh pemerintah Orde Baru. Seperti dalam bidang pendidikan, pemerintah juga terus mengusahakan peningkatan jumlah dan perbaikan mutu. Pemikiran pembaharuan pendidikan yang dirintis oleh Komisi Pembaharuan Pendidikan Nasional pada tahun 1970-an telah berusaha memutuskan konsep dan sistem pendidikan nasional yang bersifat semesta, dalam arti meliputi semua elemen kebudayaan (Logika, etika, ketrampilan, nilai moral dan spritual). Usaha pembaharuan tersebut juga diharapkan menyeluruh (menyentuh semua jenis dan jenjang pendidikan) dan terpadu dalam arti membina secara jelas kaitan fungsional antar jenjang serta antar jenis pendidikan.

Sementara itu, tingkat pendidikan umat Islam di Indonesia dalam dasa warsa terakhir ini memang mengalami kemajuan yang sangat pesat. Kemajuan tersebut terutama terjadi sebagai akibat dari perubahan dan penyesuaian dalam berbagai aspek sistem pendidikan. Terjadinya dinamika perubahan dalam pendidikan Islam di Indonesia sejak masa penjajah sampai saat ini, merupakan indikasi yang kuat bahwa sistem pendidikan Islam dapat menyesuaikan diri dan beradaptasi dengan perkembangan masyarakat. Perkembangan itu menggambarkan pula bahwa masyarakat Islam mampu melakukan pembaharuan dalam sistem pendidikan yang mereka geluti. Meskipun demikian, banyak pengamat melihat bahwa masih banyak masalah yang 
timbul dalam lembaga kependidikan Islam di Indonesia yang membutuhkan perhatian. Buchori (1989) misalnya, menyatakan bahwa sistem pendidikan Islam yang belaku sekarang masih belum memenuhi harapan sebagian besar anggota masyarakat santri sendiri. Problem yang dihadapi yaitu mengenai kaitannya dengan dunia pendidikan umum dan mengenai struktur internal yang terdapat dalam tubuh lembaga kependidikan Islam di Indonesia dewasa ini.

Dalam upaya membeberkan persoalan di atas, ada tiga problematik yang harus dipecahkan secara cermat dan baik dalam persoalan pendidikan Islam. Tiga jenis persoalan-persoalan itu ialah: (1) Persoalan landasan atau fundasional (foundational problelm of education); (2) persoalan struktural lembaga kependidikan (Struktural problem of educational institution); (3) persoalan operasional pendidikan (operational problems of education).

Masalah-masalah landasan pendidikan dalam pendidikan Islam di Indonesia ialah meliputi masalah yang mendasari segenap praktek pendidikan dan mendasari segenap lembaga pendidikan yang dibangun untuk melaksanakan tindakan-tindakan pendidikan. Landasan-landasan itu dapat berwujud landasan filosofis, psikologis dan politis.

Masalah-masalah struktur lembaga pendidikan ialah keseluruhan masalah yang berhubungan dengan struktur lembaga pendidikan Islam yang digunakan untuk melaksanakan tindakan pendidikan. Masalah yang paling mendasar sampai sekarang ini ialah persoalan sistem pendidikan Islam.

Demikian pula masalah-masalah operasional pendidikan dalam pendidikan Islam di Indonesia merupakan keseluruhan masalah tentang cara melaksanakan tindakan pendidikan, baik dalam lingkungan keluarga, lingkungan pendidikan persekolahan, maupun lingkungan pendidikan jalur luar sekolah.

Permasalahan pendidikan Islam di Indonesia memang tidak dapat dilepaskan dari permasalahan sosial, ekonomi dan politik. Perubahan salah satu daripadanya akan memberi dampak kepada yang lain. Dalam hubungan dengan permasalahan ini Prof. Bahtiar Rivai (1971) mengemukakan apa yang ia namakan sebagai salah satu "paradok pendidikan", di satu pihak pendidikan sejak dulu selalu dianggap sebagai penggerak dari kemajuan ilmiah, teknologi dan kebudayaan, di lain pihak terdapat fakta tentang kurangnya adaptasi pendidikan terhadap masyarakat dan fakta bahwa pendidikan selalu ketinggalan dari perkembangan cepat di bidang ilmu pengetahuan, teknologi dan kebudayaan. Kalau demikian, selalu dan senantiasa terdapat divergensi pendapat mengenai misalnya peran-peran lembaga pendidikan dan output pendidikan sebagai "agen of change".

"Ten educational issues of the future" (lihat Coombs and Dubbledam, 1982) sebagai akibat perubahan-perubahan di bidang politik, ekonomi dan demografi dalam skala nasional maupun internasional sangat berpengaruh terhadap kedudukan lembaga kependidikan Islam di Indonesia, meliputi: (1) kuantitatif problem yang ditimbulkan pesatnya jumlah penduduk, (2) tingginya biaya pendidikan, (3) pemerataan pendidikan, (4) ketidakseimbangan antara output dengan lapangan kerja, (5) mutu dan relevansi pendidikan, (6) kaitan pendidikan -jalur persekolahan dan luar persekolahan dengan pendidikan seumur hidup, (7) pengaruh pendidikan dengan kebudayaan, (8) usaha mempercepat kelambanan dalam pendidikan, (9) perencanaan dan 
kepemimpinan dalam kaitannya dengan perubahan sosial, ekonomi, politik akibat renovasi, desentralisasi dan partisipasi, dan (10) kerjasama nasional dan internasional.

Tulisan ini merupakan hasil observasi dan analisis dari referensi dan data empirik tentang kedudukan lembaga kependidikan Islam di Indonesia, dilihat dari tiga persoalan dan sepuluh issue seperti tersebut di atas.

\section{Lembaga Pendidikan Islam sebagai Sub Sistem Pendidikan Nasional}

Uraian-uraian tentang persoalan dan problematik kedudukan lembaga lembaga kependidikan Islam di Indonesia sudah sejak lama dan banyak dibicarakan di referensireferensi. Diawali oleh LP3ES dengan penelitiannya tentang Pesantren (1974), para sarjana Indonesia di antaranya Amin Rais (1987), "Muslim society", higher education and development: The Case of Indonesia, Kuntowijoyo (1991) dalam paradigma Islam, dan terakhir tulisannya Steenbrink (1986) sarjana Barat yang mengungkapkan pesantren, madrasah dan sekolah. Dalam diskusi ini belum banyak dibahas secara operasional tiga persoalan pokok dalam pendidikan dan sepuluh issue pendidikan seperti tersebut di atas kaitannya dengan kedudukan pendidikan Islam di Indonesia dewasa ini.

Di tengah aneka kegelisahan yang masih tampil ke permukaan kehidupan umat Islam, kita perlu membangun citra optimisme dalam wacana mengenai pendidikan Islam di Indonesia. Telaah para sarjana muslim tiba pada kesimpulan, bahwa pendidikan Islam di Indonesia akhimya akan mampu menjadi sub-sistem Pendidikan Nasional sebagaimana dicitacitakan, yaitu mampu berpartisipasi dalma upaya membawa banigsa Indonesia modem sesuai dengan ajran Islam dan tetap menampilkan wajah Pancasila. Ada tiga pembenaran teoritik yang dapat mendukung kesimpulan tadi. Pertama, posisinya yang mayoritas. Kedua, semakin berkembangnya studi-studi modern keislaman. Ketiga, semakin terbukanya pemerintah Orde Baru dalam mempersilahkan pemikiran-pemikiran keagamaan sebagai sumber dan sekaligus masukan untuk menyusun garis-garis besar dan arah pembangunan nasional.

Pertama-tama kita harus menyadari bahwa semua kelemahan-kelemahan yang menjadi persoalan dan problematik pendidikan' Islam di Indonesia sampai saat ini adalah produk sejarah yang berkembang sejak zaman sebelum kemerdekaan.

Pendidikan Islam berkembang dari tradisi pesantren yang semata-mata menekankan kepada pembinaan batin dan olah kerokhanian, sedangkan pendidikan dan pengajama di bidang ilmu pengetahuan umum berasal dari tradisi Eropa Barat yang menekankan kepada kecerdasan. Dua jenis pendidikan dengan tradisi sangat terpisah ini berkembang cukup lama yaitu dari sejak akhir abad ke-19 sampai dengan tahun 1970an. Pola pendidikan ganda tersebut menimbulkan dua golongan masyarakat terpelajar yang terpisah, yaitu antara kelompok cendekiawan dan kelompok ulama, baik dalam pergaulan, kebiasaan dan pola pikir. Hal ini mengakibatkan timbulnya berbagai ketimpangan dan ketidakserasian dalam kehidupan masyarakat.

Pertentangan antara kelompok cendekiawan dan ulama terjadi cukup mendalam, terutama akibat kebijaksanaan kultural Pemerintah dan pendidikan kolonial Belanda. Oleh karena itu upaya penyatuan kedua kelompok itu, sejak penyerahan kedaulatan dari kolonial Belanda, belum dapat tercapai dengan mudah. Pemerintah Indonesia mulai mengupayakan terpadunya 
dua jenis pendidikan yang bersifat dichotomik tersebut. Konsep dasar untuk memecahkan masalah tersebut telah dirumuskan dalam bentuk sistem pendidikan yang integral; yang bertujuan untuk mewujudkan keselarasan, keserasian dan keseimbangan antara penguasa ilmu pengetahuan umum dan ilmu agama. Terhadap pendidikan yang mengutamakan ilmu pengetahuan umum dimasukkan ke dalamnya pendidikan agama, dan sebaliknya terhadap lembaga pendidikan keagamaan dimasukkan ke dalamnya pengajaran. pelbagai cabang ilmu pengetahuan, teknologi dan seni sehingga tercipta pembentukan pribadi manusia Indonesia seutuhnya.

Upaya pemerintah di bidang pendidikan tersebut telah terbentang jembatan yang menghubungkan bersatunya golongan cendekiawan dan kaum agama di lingkungan masyarakat Islam, yaitu dengan berkembangnya empat macam pendidikan Islam yang dapat dilihat perbedaannya dari segi program serta praktek-praktek pendidikan yang dilaksanakan. Keempat macam pendidikan Islam itu ialah: (1) pendidikan pondok pesantren; (2) pendidikan keagamaan (dari Madrasah Ibtidaiyah sampai IAIN); (3) pendidikan umum yang berciri khas Islam; dan (4) pendidikan agama Islam di lembagalembaga pendidikan umum.

Proses pengintegrasian dan pencarian sifat dichotomik sistem pendidikan nasional kita terus berjalan dan nampaknya semakin lancar. Pembinaan terhadap lembagalembaga pendidikan Islam terus dilakukan, baik oleh masyarakat penyelenggara pendidikan Islam tersebut maupun oleh pernerintah. Keempat macam pendidikan Islam tersebut di atas tercakup dalam dan merupakan bagian dari sisdiknas yang diatur dalam UUSPN (lihat UU RI nomor 2 th. 1989), baik sebagai satuan pendidikan sekolah maupun sebagai satuan pendidikan luar sekolah, baik pada pendidikan umum maupun pada pendidikan keagamaan, dari jenjang pendidikan dasar sampai pendidikan tinggi.

Dari uraian di atas, persoalan dan problematik lembaga pendidikan Islam di Indonesia memiliki kesempatan optimisme yang sangat luas dan terbuka lebar untuk dibenahi dan dikembangkan, di antaranya dengan meningkatkan mutu lembagalembaga pendidikan Islam dan pendidikan agama pada sekolah-sekolah umum sehingga pendidikan Islam mampu menjalankan fungsinya secara optimal dalam upaya mencapai tujuan pendidikan sebagaimana ditegaskan dalam GBHN, yaitu membentuk manusia Indonesia yang beriman dan bertakwa kepada Tuhan Yang Maha Esa. Di samping itu kita tidak dapat hanya mengandaikan pada jalur pendidikan sekolah yang hanya mampu melayani pendidikan bagi anak usia sekolah saja. Kita perlu mengembangkan muatan sistem pendidikan Islam yang lebih mampu melayani masyarkaat luas meialui jalur pendidikan luar sekolah. Perkembangan masyarakat kita sekaran gini sedemikian kompleksnya sehingga kebutuhan akan pelayanan pendidikan luar sekolah dalam berbagai bidang, juga dalam bidang agama, akan semakin bertambah luas. Dalam upaya memenuhi kebutuhan masyarakat yang semakin meningkat akan pengetahuan tentang agama Islam, tidak mungkin dilayani hanya dengan pendidikan agama Islam yang dimasukkan ke dalam kurikulum sekolah, atau pada lembagalembaga pendidikan keagamaan.

Akhirnya kita bersepakat bahwa kedudukan pendidikan Islam dalam UndangUndang Nomor 2 tahun 1989 tentang Sistem Pendidikan Nasional berada pada tempat 
yang sangat strategis dalam PJP II. Alasannya adalah, bahwa pendidikan Islam sama dan tidak dapat dipisahkan dengan komponen-komponen pendidikan lainnya yang merupakan satu kesatuan keutuhan intervensi untuk meningkatkan kemampuan peserta didik dalam berbagai dimensi. Dimensi itu meliputi: (1) dimensi rasioyang bersumber pada ilmu pengetahuan, teknologi dan seni, (2) dimensi kesadaran yang bersumber pada akidah, keyakinan, kepercayaan dan solidaritas sosial, (3) dimensi kelembutan dan kehalusan perasaan yang bersumber pada kepekaan dan keharuan, dan (4) dimensi pengalaman yang bersumber pada kedaulatan, ketrampilan dan pengalaman.

Saya berpendapat, apabila tiga persoalan dalam pendidikan Islam di Indonesia itu dibijaksanai dan dikembangkan meliputi empat dimensi tersebut di atas, maka akan sanggup memecahkan sepuluh issue pendidikan yang saya sebutkan di atas pula.

\section{Agama dan Modernisasi Pendidikan}

Pada waktu menyimpulkan analisisnya mengenai "Isiam di Indonesia", Soebardi (1978) mendasarkan harapannya mengenai peran sentral serta daya kemampuan sistem pendidikan untuk melakukan penyesuaian dengan kondisi yang menghimpit umat Islam. Pernyataan secara lengkap menarik untuk diperhatikan

Di dalam kenyataan hidup masyarakat Indonesia sekarang, terdapat kesempatan yang terbuka bagi umat Islam, terutama pemimpin-pemimpin untuk terus berusaha keras memperjuangkan kepentingan umatnya menuju kebahagiaan hidup. Untuk mencapai cita-cita yang luhur itu, umat Islam Indonesia masih harus menghadapi tantangan berganda yang datang dari dalam dan dari luar. Dari dalam, Islam di Indonesia harus memerangi keterbelakangan, kebodohan, kemiskinan dan stagnasi yang terdapat di antara umatnya. Dariluar, Islam masih harus menghadapi dan memberikan jawaban terhadap tantangan yang berbentuk pengaruh paham baru dan unsur-unsur kebudayaan yang datang dari dunia modern, yang di Indonesia tak mungkin dielakkan oleh siapapun juga.

Jawaban untuk semua tantangan ini kelihatannya akan harus bertumpu pada nasib yang selama ini kelihatan menjadi kekuatan dalam dari Islam, yakni kemampuannya menyesuaikan diri dengan keadaan dan fleksibilitas dari sistem pendidikannya, dan dengan begitu mampu menjaga kelestariannya sendiri.

Secara historis dan sosiologis penyimpulan Soebardi itu mengandung kebenaran bila kita mengungkapkan kembali peta dasar pendidikan Islam di Indonesia. Dia melihat suatu daya adaptasi kultural yang menarik pada lembaga kependidikan Islam di Indonesia dalam menjawab tantangan modernisasi tanpa kehilangan esensi religiousitas atau ke-Islam-annya.

Pondok pesantren sebagai sistem pendidikan Islam yang tertua di Indonesia. Tujuan pokok sistem pendidikan ini secara tradisi adalah berupaya untuk menjadikan anak didik sebagai manusia yang memiliki pengetahuan yang baik tentang ajaran Islam, menghayatinya kemudian mengamalkannya dalam kehidupan seharihari (tafaqquh fi al dien). Inti kurikulum terbatas pada pembacaan AI Qur'an, tafsir, tauhid, fiqih dan penguasan bahasa Arab. Meskipun isi dan medan jenis pendidikan pesantren ini sangat terbatas, namun pada abad ke-19 mampu menelorkan kebangunan Islam (baca Kahin, 1980, nasionalisme 
Islamisasi dan revolusi di Indonesia). Secara internal dalam proses Islamisasi pondok pesantren telah melaksanakan fungsi pemeliharaan dan pengubahan. Seperti diketahui tatkala awal Islamisasi berlangsung tradisi mistik dan animistik merupakan corak khas masyarakat, dan kehadiran pesantren telah mampu melakukan perubahan ke arah Islam yang lebih murni atau lebih sunni.

Dari gambaran di atas dapatlah dikemukakan pendapat bahwa proses ke arah ortodoksi (proses re-Islamisasi terhadap kaum abangan) memperoleh dasar psikologis yang kuat untuk membina orang Islam abangan, di samping itu orang santri selalu merasa memiliki dasar moral yang kuat untuk membina keagamaan orang abangan. Ajaran Islam yang mengharamkan pola kehidupan boros, perjudian, pelacuran, pencurian dan pelanggaran sosial, karenanya pembinaan kehidupan kemasyarakatan yang bersifat positif memperoleh respon yang baik dalam membina penyebaran keislaman di daerahdaerah. Artinya pesantren mempunyai peranan yang cukup berarti, dapat dikategorisasikan sebagai peran yang mumi bersifat keagamaan dan kemasyarakatan.

Pada awal pertumbuhannya, pesantren tumbuh dan berkembang sebagai bagian dari masyarakat desa yang ada di sekelilingnya. Kekuatan motivasi para pendidik dan penyelenggara pesantren bukanlah semata-mata merupakan kepentingan ekonomis, namun merupakan amanat yang mewajibakan setiap muslim, dari "ayunan ibu" sampai "liang lahat" untuk mencari dan mengajarkan ilmu agama Islam. Bahkan menurut mereka lembaga pesantren dikatakan sebagai benteng umat Islam.

Perkembangan-perkembangan baru yang terjadi (terutama setelah pemerintah
Indonesia mengembangkan sistem pendidikan umum profesional), telah memberi stimulan bagi lahirnya perubahan sosial dalam kehidupan umat Islam di Indonesia. Menghadapi suasana ini, umat Islam lalu tidak hanya mengembangkan pendidikan pesantren saja melainkan juga sekolah-sekolah umum profesional. Selain itu, perlu pula diperhatikan terjadinya perubahan di bidang sosial, politik dan ekonomi, menyadarkan mereka akan pentingnya memajukan pendidikan umat Islam. Perkembangan ini membawa akibat munculnya perubahan, terutama dalam cara berfikir. Perkembangan tersebut selanjutnya menumbuhkan kesadaran bagi kelompok pemimpin Islam untuk lebih mendalami dan menghayati hakekat dan arti dari ajaran islam melalui proses pendidikan dan dakwah.

Dalam konteks di atas amatlah menarik untuk dikaji ulang tulisan Dr. M. Amien Rais tentang "Muslim Society, Higher Education and Development": The case of Indonesia, bahwa gambaran mengenai masyarakat muslim di Indonesia ditelaah dari berbagai kecenderungan dua organisasi besar seperti NU dan Muhammadiyah yang kemudian membentuk persepsi masyarakat muslim Indonesia tentang pendidikan Islam.

Bagi kalangan Nahdlatul Ulama, yang mendominasi lembaga pendidikan pesantren, telah pula melakukan perubahan penting dengan membuka pondok untuk murid-murid wanita, dan dengan dikenalkannya sistem madrasah, dan pengajaran pengetahuan umum. Perubahanperubahan yang berarti dalam pola pendidikannya disebabkan adanya keinginan sangat kuat untuk menerapkan sistem sekolah dengan program tambahan pengembangan ketrampilan. Dalam sistem tersebut digabung antara pelajaran keislaman, pengetahuan umum dan ketrampilan teknis, dengan harapan agar 
para santri akan mampu membawakan orientasi baru dalam pandangan hidupnya. Perubahan drastis ini akhirnya berakibat semakin kuatnya keinginan untuk menciptakan tenaga-tenaga elit dalam ilmu keagamaan di beberapa pesantren. Watak pendidikan pesantren yang semula populis, dimana masing-masing santri dapat belajar dengan tidak terhalang kekurangan biaya, kini menjadi pendidikan terbatas dengan waktu dan program yang terbatas pula. Pendidikan pesantren yang semula bersifat elastis, kini menjadi kaku dan seragam. Meskipun demikian, pesantren masih tetap memiliki watak populisnya, yakni dengan sifat elastisnya program individual yang telah berlangsung selama bertahun-tahun, minimal dalam pengajaran pengajian-pengajian yang bersifat ekstrakurikuler. Di samping itu, kecenderungan untuk menumbuhkan pendidikan berwatak elastis juga berjalan cukup kuat seperti yang terjadi di Pondok Modem Gontor, Pesantren Pabelan dan juga pesantren-pesantren lainnya.

Dalam kasus-kasus tertentu, di mana pesantren harus menyesuaikan dengan kebutuhan daerah perkotaan dan aspirasi tertentu, mereka mengembangkan beberapa jenis variasi dalam skala kecil yang bersifat individual. Di samping penyelenggaraan sistem pesantren, dilengkapi pula lembaga pendidikan madrasah bahkan sekolahsekolah umum. Hal semacam ini sudah lama terjadi di beberapa lembaga pendidikan pesantren di kota-kota besar, seperti di Jakarta (pesantren Asy-Syafiiyah, pesantren Darun Najah, dll.), di Ujung Pandang (pesantren IMMIM) dan di tempat-tempat lainnya. Diversivikasi yang dihasilkannya semakin menonjolkan watak umum populis dari sistem pendidikan itu sendiri. Dengan diversifikasi seperti ini akan tercapai kedewasaan dan keseimbangan dalam pandangan hidup yang dimiliki oleh pesantren dalam menciptakan etik sosial dengan kebutuhan masyarakat tersebut.

Pesantren yang di dalamnya dilengkapi dengan sekolah madrasah dan madrasah diniyah akan menumbuhkan sikap hidup tunduk kepada kyai, kepada ustad dan orientasi kehidupan yang lebih bersandar kepada kemampuan sendiri. Secara konkrit hal itu lalu dipusatkan kepada kesediaan untuk membiayai sistem pendidikannya dan kepada pengembangan watak tolong menolong (fi'lul-birn) yang bersifat kolegial. Pesantren dikenal mempunyai fungsi ganda semacam itu.

Berbeda dengan Muhammadiyah yang sejak semula mendasarkan sistem pendidikannya dengan sistem sekolah, yang bertujuan antara lain: (1) mengembalikan amal dan perjuangan umat pada sumber Qur'an dan Hadits, bersih dari bid'ah dan khurafat, (2) menafsirkan ajaran Islam secara modem, (3) memperbarui sistem pendidikan Islam secara modern sesuai dengan kehendak dan kemajuan zaman, dan (4) membebaskan umat dari ikatan tradisional, konservativisme, taqlidisme, dan formalisme yang membelenggu kehidupan umat. Lembaga pendidikan seperti ini memiliki ide dasar perubahan dan perkembangannya dalam garis besarnya dapat digambarkan sebagai kebangkitan, pembaharuan bahkan pencerahan.

Pada sarasehan tentang pendidikan Muhammadiyah dan perubahan sosial, di Yogyakarta, Kuntowijoyo (1985) mengemukakan bahwa sistem pendidikan Muhammadiyah ditujukan untuk mempertahankan iman dan menyesuaikan lembagalembaga keagamaan dengan perubahan sosial. Sistem sekolah yang dikembangkan Muhammadiyah adalah contoh yang paling jelas dari usaha ini. Muhammadiyah menyadari bahwa untuk hidup dalam 
masyarakat industri orang harus belajar melalui pendidikan formal yang mengajarkan ketrampilan-ketrampilan tertentu. Substansi, pross dan produk pendidikan formal itu sangat berbeda dengan pendidikan pondok pesantren. Pendidikan Muhammadiyah berusaha memenuhi pasaran kerja baru dalam birokrasi, industri, pendidikan, perdagangan, kesehatan dan sebagainya. Muhammadiyah telah mempersiapkan anggota masyarakat dengan etik, keahlian dan lembaga yang sesuai dengan perkembangan masyarakat industri dan pedagang. Pengusaha-pengusahayang lahir di kalangan Muhammadiyah seperti nampak dalam beberapa kelompok semacam Kota Gede, Karang Kajen, Prawirotaman dan Kauman di Yogyakarta, Bakonang di Surakarta, Pekajangan di Pekalongan dan beberapa temaptyang lain yang tersebar $\mathrm{di}$ seluruh Indonesia telah menghias perkembangan sejarah sosial ekonomi pada era sebelum dan sesudah kemerdekaan.

Demikianlah pola pengembangan dan perubahan di lembaga-lembaga pendidikan Islam, tidak lain merupakan pantulan pendidikan dalam rangka pemikiran sosiologik, yang menginginkan lembaga pendidikan mempunyai arti sosialistik. Karena pendidikan dan perubahan sosial adalah proses kodrati sebagai product of the interaction of many factors, sehingga memiliki variabel dan dimensi permasalahan yang hampir-hampir tidak terbatas. Gejala itu dapat mengenai perubahan tata nilai, norma-norma, perilaku individu, organisasi, kekuasaan dan wewenang, susunan kelembagaan dalam masyarakat dan sebagainya. Gejala perubahan itu bukanlah lompatan-lompatan besar yang dituntut sebagian masyarakat. Kesulitan itu antara lain karena kondisinya memang sangat lemah dna kurang penunjang dari luar. Dengan modal dan sarana itu tidak mungkin lembaga pendidikan Islam mampu melakukan peningkatan yang spektakuler.

Sebenarnya permasalah pendidikan Islam di Indonesia, tetapi juga diderita oleh lembaga-lembaga pendidikan di seluruh negara-negara yang sedang berkembang. Myrdal (1965) dalam mengemukakan permasalah pendidikan di negara-negara yang sedang berkembang menegaskan adanya hubungan yang erat antara pendidikan dengan aspirasi dan kehendak masyarakat, sehingga dalam mengidentifikasi permasalahan itu tidak mengabaikan faktor tradisi dan pengaruh pendidikan dewasa ini. Myrdal mengemukakan tiga hal yang mempengaruhi pendidikan di negara-negara yang sedang berkembang, ialah: (1) warisan tradisi prakolonial, (2) pengaruh pendidikan barat selama masa penjajahan, (3) apa yang dikatakan Myrdal sebagai the dead hand or the past. Tiga hal itu hampir mempunyai pengaruh yang sama terhadap keadaan pendidikan di Indonesia dewasa ini.

Tradisi pra-kolonial dan arah pendidikan masa penjajahan cenderung mempertajam diferensiasi etnis dan kultural. Pendidikan justru akan mempertebal sentimen primordial dan mempertebal perbedaan etnis yang menjadi penghambat integrasi nasional. Pengaruh pendidikan Barat selama masa penjajahan, yang berorientasi pada status achievement dan mempertajam stratifikasi sosial. Sekolah memang dipersiapkan mengisi strata sosial tertentu, dalam hal ini birokrasi pemerintahan. Karenanya pendidikan akan menciptakan kultur pternalistik yang justru akan menghambat proses pengembangan ilmu pengetahuan, karena hanya berorientasi pada kepentingan untuk mencetak birokrat. Di samping itu adanya pemisahan dan spesialisasi yang tajam dalam pendidikan menciptakan diferensiasi antar mereka yang menempuh 
pendidikan kejuruan, pendidikan umu dengan mereka yang menempuh pendidikan agama. Untuk terakhir ini menimbulkan kesan bahwa lembaga pendidikan Islam dianggap kurang laku di pasaran tenaga kerja dibandingkan dengan lembaga pendidikan umum lainnya.

Akhirnya optimisme kita berangsurangsur akan terwujud, karena kedudukan lembaga kependidikan Islam di Indonesla merupakan salah satu varian kekuatan pendidikan nasional dalam rangka membentuk masyarakat islami, kehidupan Islami, dna pembentukan watak serta perilaku Islami yang senantiasa berhadapan dengan proses perubahan yang amat kompleks. Dampak yang timbul atas perubahan tersebut tidak selalu searah dengan orientasl Islami. Secara fungsional pedagogis, masalah utama yang dihadapl adalah bagaimana memperslapkan tamatannya agar memiliki kemampuan dalam menjawab segenap tantangan yang mereka hadapi secara memadal di masa depan, yakni dengan sikap positip dalam menghadapi proses pembangunan. Adanya peremajaan sistem dan pengembangan sistem pendidikan Islam di Indonesla merupakan sikap antisipatif dan partlsipatif dalam menghadapi proses pembangunan agar terjadi proses kongruensi antara pembangunan nasional dalam rangka menuju kehidupan modern dan' arus pendidikan Islam.

\section{Penutup}

Bahwa eksistensl lembaga kependidikan Islam di Indonesia mengalami kemajuan yang pesat. Perkembangan dan kemajuan yang dicapal merupakan suatu daya adaptasi kultural dalam menjawab proses pembangunan dan perubahan sosial yang terjadi tanpa kehilangan esensi keIslaman-nya. Masyarakat Islam di Indonesia sependapat bahwa pendidlkan Islam merupakan bagian dari, sistem kehidupan Islam, yaitu suatu proses internalisasi dan soslalisasi nilai-nilai moral Islam melalui sejumlah informasi atau pengetahuan, sikap, perilaku dan budaya guna memecahkan persoalan-persoalan hidup, mempertahankan hidup, dan meningkatkan kualitas hidup peserta didik dan generasi muda.

Peremalaan dan pengembangan sistem darl lembaga pendidlkan Islam membawa perubahan kepada tlga persoalan pendidikan, yaitu persoalan fondasional, persoalan struktural dan persoalan operasional dan nantinya akan sanggup menjawab sepuluh issue permasalahan pendidikan dewasa inl. Dengan demikian perkembangan pendidikan di kalangan masyarakat Islam terjadi perubahan balk dalam segl kualitas maupun dalam segi kuantitas.

\section{Daftar Pustaka}

Bukharl, Mukhtar. 1989. Pendidikan Islam di Indonesia: Problema Masa KInI dan Perspektif Masa Depan, dalam M: Dawam Rahardjo (penyunting), Islam Indonesla Menatap masa Depan. Jakarta: P3M.

Coombs and Dubbeldam. 1982. "Waw goes. the world educational crisis", Higher Education and Research (unpublish).

Kuntowiljoyo, 1985. Muhammadlyah dalam Perspektif Sejarah, dalam M. Amien Rais $(\theta, d), \quad$ Pendldikan Muhammadlyah dan Perubahan Sosial, Yogyakarta: PLP2M.

Kuntowiloyo. 1991. Paradigma Islam, Jakarta: Mizan. 
Myrdal, Gunnar. 1969. Asian Drama: An Iquairy Inte The Proverty of Nation, vol. III. USA: Penguin Book.

Rahardjo, M. Dawam. 1974. Pesantren dan Perubahan Sosial, Jakarta: LP3ES

Rais, M. Amien. 1987. "Muslim society, higher education and development: The case Indonesia", dalam Sharon Ahmat dan Sharon Sidduque, ed., Muslim Society Higher Education and Development in Southeast Asia, Institute of Southeast Asia Studies, Singapore.
Rivai., Bahtiar. 1971. Pembaharuan Pendidikan di Indonesia. Jakarta: Depdikbud.

Steenbrink, Karel A. 1986. Pesantren, Madrasah, Sekolah: Pendidikan islam Dalam Kurun Modem, Jakarta: LP3ES.

Soebardi, S. 1978. Islam di Indonesia. dalam Prisma. Vol. Ekstra. 